\title{
Optimization Neuro Fuzzy using Genetic Algorithm for Diagnose Typhoid Fever
}

\author{
Muhamad Nasrul Fata ${ }^{1}$, Riza Arifudin ${ }^{2}$, Budi Prasetiyo ${ }^{3}$ \\ ${ }^{1,2,3}$ Computer Science Departement, FMIPA, Universitas Negeri Semarang, Indonesia \\ Email: 'nasrul10fata@gmail,com, ${ }^{2}$ riza.arifudin@gmail.com, ${ }^{3}$ budipras@mail.unnes.ac.id
}

\begin{abstract}
Neuro Fuzzy is one method in the field of information technology used in diagnosing an disease. The application of Neuro Fuzzy is to identify disease. Genetic algorithms can be used to find solutions without paying attention to the subject matter specifically, one of which is an optimization problem. Typhoid or typhoid fever is a disease caused by Salmonella enterica bacteria, especially its derivatives. The diagnosis of typhoid fever is not an easy thing to do. This is because some of the indications experienced by patients also appear in other diseases. The number of patients with typhoid fever that requires accuracy in diagnosing typhoid fever based on indications caused. Based on this background this study aims to assist in the diagnosis of typhoid fever with 11 indication variables. This study uses medical record data for typhoid fever in 2017 Tidar Magelang Hospital. The method used is Neuro Fuzzy which optimizes the value of the degree of membership with genetic Algorithms. Then the value of the degree of neuro fuzzy membership is more optimal. The results of this optimization are the diagnosis of typhoid fever based on the variable of indications entered. From the research results obtained from the neuro fuzzy method get an $80 \%$ accuracy value and neuro fuzzy optimization results with genetic algorithms with a value of pc $0.5, \mathrm{pm} 0.2$ and max generation 25 the value of accuracy increases to $90 \%$. Suggestions from this study, need to add more specific indication variables.
\end{abstract}

Keywords: Neuro Fuzzy, Genetic Algorithm, Typhoid Fever, Diagnosis, Optimization, Accuration

\section{INTRODUCTION}

In the subdivision of information technology there are several methods that can be used to help everyday life, one of which is to diagnose an disease. One way of diagnosing disease, fuzzy logic can be used to present the linguistic truth values of a set of members [1] and alternative ways of thinking that can model complex systems using knowledge and experience that have logic starting as a study of language in argumentation and persuasion [2] . One of the fuzzy methods used in diagnosing an disease is Neuro Fuzzy. One application of this method is in Neuro Fuzzy research to diagnose Schizophrenia. In the study obtained a diagnosis with a percentage of $100 \%$ based on expert judgment on system trials [3]. The application of Neuro Fuzzy into 
information systems that can identify diseases, will greatly assist in the process of diagnosing activities quickly and precisely. Methods that combine fuzzy logic and artificial neural networks are commonly called hybrid systems [4]. Compared with reverse propagation neural networks, the ANFIS learning process only requires a few tens of epochs [5].

Genetic algorithms do not require much mathematical concepts, and can treat all forms of objective functions and constraints. The problem of optimization of constrained functions with integer coding, can be solved by genetic algorithms. So that the value of the function of reliability, cost and weight of a system can be produced [6]. Genetic algorithm (GA) is employed to search the optimal solution on the response surfaces modeled [7].

Typhoid fever or abdominal typhus is an acute infectious disease of the digestive tract that has the potential to be a multisystemic disease caused by Salmonella typhi [8]. Indication include high fever, malaise, headache, nausea, loss of appetite, constipation or diarrhea, pink spots on the chest (Rose spots), and enlargement of the spleen and liver [9].

Typhoid fever is a health problem in the world especially in developing countries such as those found endemic throughout Africa, South America, East Asia and especially in South Asia [10]. Typhoid or typhoid fever is a disease caused by Salmonella enterica bacteria, specifically its derivatives, Salmonella typhii [11]. This disease can be found all over the world, and is spread through food and beverages that have been contaminated by feces [12]. Typhoid can cause septicemia, and reported an average incidence of around 2,500 per 100,000 population [13].

The diagnosis of typhoid fever is not an easy thing to do. This is because some of the indication experienced by patients also appear in other diseases. Typhoid basil, the main indication of typhoid fever is continuous high heat for 2 weeks [14]. This fever can be followed by other non-typical indication such as diarrhea, anorexia or coughing [15].

Based on the problem of the number of typhoid fever sufferers and requires accuracy in diagnosing typhoid fever based on indication caused, it is necessary to use the Neuro Fuzzy method which will then be optimized again using Genetic Algorithms and implemented into the system. The proposed system is built with the aim of providing a decision support which adopts genetic algorithm technique to optimize the performance of a neuro-fuzzy diagnostic method platform with the capability to aid medical practitioners in administering efficient diagnosis outcome for patients [16]. So that it is expected to help speed up the diagnosis of typhoid fever that may be suffered. Therefore this study applies the Neuro Fuzzy method optimized with Genetic Algorithms for the Diagnosis of Typhoid Fever based on indication variables obtained from medical record data on typhoid fever in Tidar Hospital Magelang in 2017. 


\section{METHODS}

Data processing is done by calculating the results of diagnosis with the Neuro Fuzzy method first. Then calculate the diagnosis with the Neuro Fuzzy method and optimize the Genetic Algorithm. Calculate the accuracy value of each diagnosis result with actual diagnosis data. The following is the flowchart of the Neuro Fuzzy method shown in Figure 1. In the neuro fuzzy optimization process with genetic algorithms performed on fuzzy membership degree values. The optimization process can be seen in the flowchart of the Neuro Fuzzy method with Genetic Algorithms as in Figure 2.

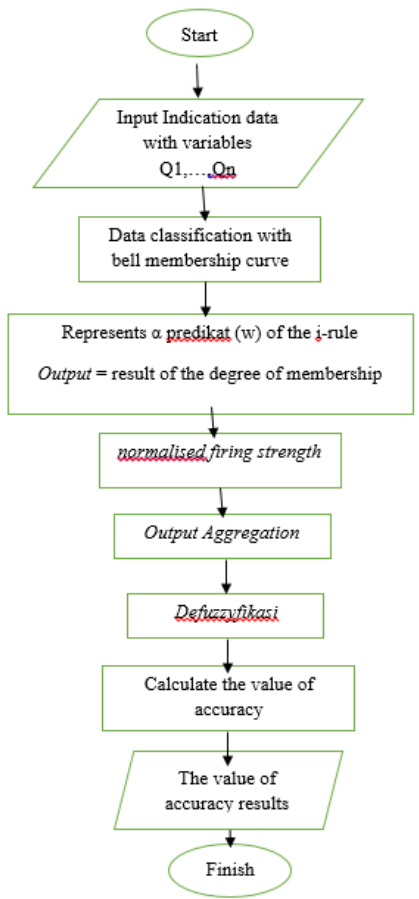

Figure 1. Flowchart of the Neuro Fuzzy Method 


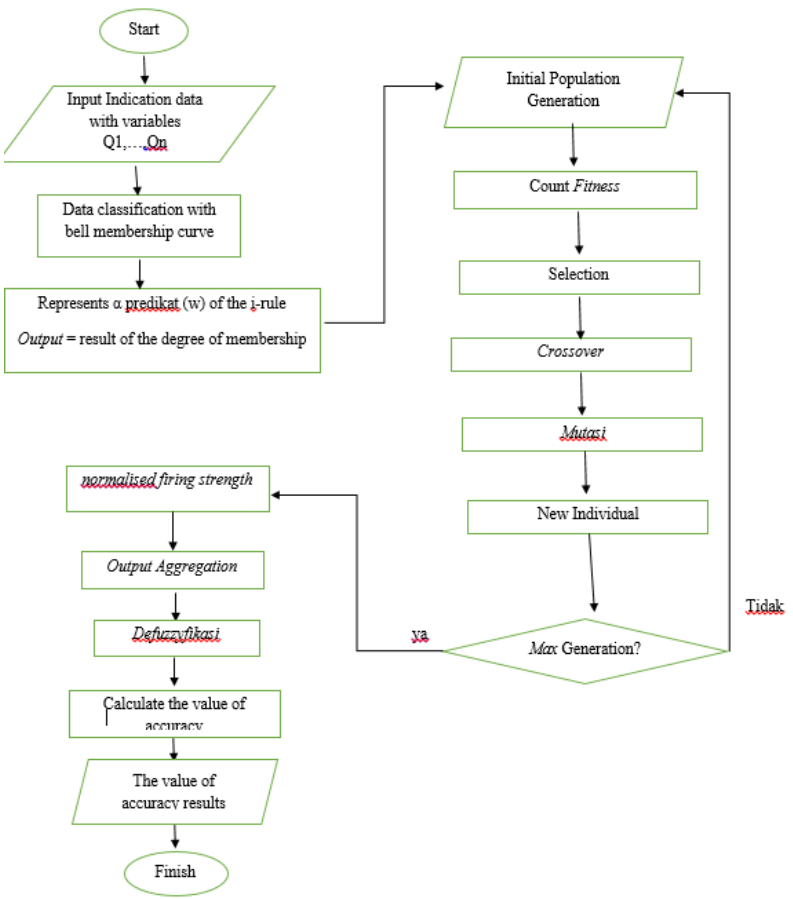

Figure 2. Flowchart of the Neuro Fuzzy Method with Genetic Algorithms

\section{RESULTS AND DISCUSSION}

The data used in this study is the medical record data of typhoid fever patients in Tidar Hospital Magelang in 2017. The data taken amounted to 100 medical record data and contained indications of typhoid fever. Indication variables taken amounted to 11 consisting of physical indications: fever, pain, dizziness, diarrhea, nausea and temperature. Whereas in the lab results the blood lab results are taken which consists of: hemoglobin, leukocytes, erythrocytes, hematrocytes, and platelets. Based on the data and literature obtained, the value of the indication variable can be seen in Table 1 .

Table 1. Variable value indications of typhoid fever patients

\begin{tabular}{ccccc}
\hline \multirow{2}{*}{ Variable } & Name of Indication & \multicolumn{3}{c}{ Criteria } \\
\cline { 3 - 5 } & & Low & Moderate & High \\
\hline Q1 & Fever (Day) & $<$ 3 Day & 3 s.d 7 Day & $>$ 7 Day \\
Q2 & Pain & No Pain (1) & Light pain (2) & Stomach/Abdomen (3) \\
Q3 & Headache & No Headache (1) & Light Headache (2) & High Headache (3) \\
Q4 & Nausea & No Nausea (1) & Nausea (2) & Nausea and Retch (3) \\
Q5 & Diarrhea & No Diarrhea (1) & Diarrhea 1-3 (2) & Diarrhea $>3(3)$ \\
Q6 & Temperature $\left({ }^{\circ} \mathrm{C}\right)$ & $<36^{\circ}$ & $36^{\circ}$ s.d. 39 & $>39^{\circ}$
\end{tabular}




\begin{tabular}{ccccc}
\hline \multirow{2}{*}{ Variable } & Name of Indication & \multicolumn{3}{c}{ Criteria } \\
\cline { 3 - 5 } & & Low & Moderate & High \\
\hline Q7 & Hemoglobin $(\mathrm{gram} / \mathrm{dL})$ & $<13$ & 13 s.d 18 & $>18$ \\
Q8 & Leukocytes $\left(\mathrm{sel} / \mathrm{mm}^{3}\right)$ & $<4$ & 4 s.d 11 & $>11$ \\
Q9 & Erythrocytes $\left(\mathrm{sel} / \mathrm{mm}^{3}\right)$ & $<4.5$ & $4 . .5$ s.d 6.5 & $>6.5$ \\
Q10 & Hematrocytes $(\%)$ & $<40$ & 40 s.d 54 & $>54$ \\
Q11 & Platelets $\left(\mathrm{sel} / \mathrm{mm}^{3}\right)$ & $<150$ & 150 s.d 450 & $>450$ \\
\hline
\end{tabular}

The value of the diagnosis variable can be seen in Table 2 .

Table 2. The diagnostic variable value of patients with typhoid fever

\begin{tabular}{cc}
\hline Level of Risk & Value \\
\hline Low & $<1$ \\
Moderate & 1 s.d. 2 \\
High & $>2$ \\
\hline
\end{tabular}

Indication data of typhoid fever patients in 2017 Tidar Hospital Magelang obtained and will be processed are shown in Table 3 .

Table 3. Indication data on typhoid fever patients in Tidar Magelang Hospital in 2017

\begin{tabular}{|c|c|c|c|c|c|c|c|c|c|c|c|c|c|}
\hline & \multirow{2}{*}{ No } & \multicolumn{6}{|c|}{ Physical indication } & \multicolumn{5}{|c|}{ Blood test } & \multirow{2}{*}{$\begin{array}{c}\text { Resu } \\
\text { It }\end{array}$} \\
\hline & & $\begin{array}{c}\mathrm{Fe} \\
\text { ver }\end{array}$ & $\begin{array}{l}\mathrm{Pa} \\
\text { in }\end{array}$ & $\begin{array}{c}\text { Head } \\
\text { ache }\end{array}$ & $\begin{array}{l}\text { Nau } \\
\text { sea }\end{array}$ & $\begin{array}{l}\text { Diar } \\
\text { rhea }\end{array}$ & $\begin{array}{l}\text { Tempe } \\
\text { rature }\end{array}$ & $\begin{array}{c}\text { Hemog } \\
\text { lobin }\end{array}$ & $\begin{array}{l}\text { Leuko } \\
\text { cytes }\end{array}$ & $\begin{array}{l}\text { Erythr } \\
\text { ocytes }\end{array}$ & $\begin{array}{c}\text { Hematr } \\
\text { ocytes }\end{array}$ & $\begin{array}{l}\text { Plat } \\
\text { elets }\end{array}$ & \\
\hline 1 & $\begin{array}{l}34- \\
42- \\
42 \\
35-\end{array}$ & 5 & 3 & 3 & 3 & 3 & 36.5 & 13.2 & 7.6 & 4.6 & 38.1 & 317 & High \\
\hline 2 & $\begin{array}{l}20- \\
42\end{array}$ & 7 & 2 & 3 & 2 & 1 & 36.5 & 9.6 & 6.2 & 4.5 & 28.4 & 204 & High \\
\hline 3 & $\begin{array}{l}01- \\
88- \\
42\end{array}$ & 8 & 2 & 2 & 3 & 2 & 36.5 & 14 & 6.5 & 5.2 & 40.6 & 145 & $\begin{array}{l}\text { Mod } \\
\text { erate }\end{array}$ \\
\hline 4 & $\begin{array}{l}10- \\
23- \\
42 \\
34-\end{array}$ & 7 & 2 & 2 & 2 & 2 & 37.5 & 15.6 & 6.9 & 5.3 & 43 & 87 & $\begin{array}{l}\text { Mod } \\
\text { erate }\end{array}$ \\
\hline 5 & $\begin{array}{c}48- \\
32 \\
32-\end{array}$ & 5 & 3 & 2 & 2 & 2 & 40 & 10.1 & 5 & 4.3 & 29.8 & 187 & High \\
\hline 6 & $\begin{array}{l}05- \\
22\end{array}$ & 8 & 3 & 2 & 2 & 2 & 36 & 11.8 & 10.8 & 4.2 & 33.2 & 225 & High \\
\hline$:$ & $:$ & : & $:$ & $:$ & $:$ & $:$ & : & $:$ & $:$ & $:$ & : & $:$ & $:$ \\
\hline $\begin{array}{l}\mathbf{1} \\
\mathbf{0} \\
\mathbf{0}\end{array}$ & $\begin{array}{c}10- \\
02- \\
15\end{array}$ & 4 & 1 & 2 & 2 & 1 & 38 & 14.5 & 3.7 & 5.7 & 43.3 & 196 & $\begin{array}{l}\text { Mod } \\
\text { erate }\end{array}$ \\
\hline
\end{tabular}

This data will be processed with neuro fuzzy process and optimization process with genetic algorithm method to get the diagnosis of typhoid fever.

The steps in the neuro fuzzy optimization process with genetic algorithms can be described as follows: 
1) Layer 1

Determine the membership function of indication data by using the bell membership function curve which can be seen in Figure 3 and will be calculated with the following equation:

$$
\mu(A)=\frac{1}{1+\left|\frac{A-c}{a}\right|^{2 b}}
$$

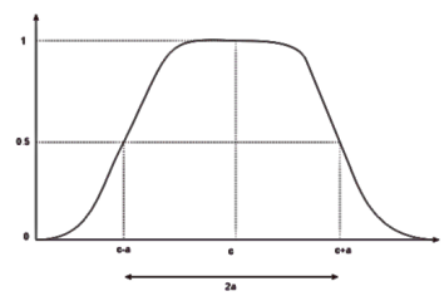

Figure 3. Membership Function Curve

From this curve the premise parameter $\mathrm{c}$ is the data center point, the premise parameter a is the center point width to the smallest or largest data, while the premise parameter $b$ is the value of the coefficient that is worth 1 to determine the value of the bell membership not reversed.

Based on the above calculations, the membership function and membership degrees are obtained as follows, which can be seen in Table 4.

Table 4. Membership function

\begin{tabular}{|c|c|c|c|c|c|c|c|c|c|c|c|c|c|c|c|}
\hline \multicolumn{3}{|c|}{ Q1 } & \multirow{2}{*}{$\begin{array}{l}\mathrm{M} \\
\mathrm{F}\end{array}$} & \multicolumn{3}{|c|}{ Q2 } & \multirow{2}{*}{$\begin{array}{c}\text { M } \\
\text { F }\end{array}$} & \multicolumn{3}{|c|}{$\cdot \cdot$} & \multirow{2}{*}{..} & \multicolumn{3}{|c|}{ Q11 } & \multirow{2}{*}{ MF } \\
\hline $\mathrm{R}$ & $\mathrm{S}$ & $\mathrm{T}$ & & $\mathrm{R}$ & $\mathrm{S}$ & $\mathrm{T}$ & & $\cdot \cdot$ & $\cdot \cdot$ & $\cdot$. & & $\mathrm{R}$ & $\mathrm{S}$ & $\mathrm{T}$ & \\
\hline 0.1 & 1 & 0.31 & 1 & 0.04 & 0.1 & 0.5 & 0.5 &.. & $\cdot$. &. &. & 0.03 & 1 & 0.16 & 1 \\
\hline
\end{tabular}

2) Optimization Membership function using Genetic Algorithm

In this process an optimization process is carried out on the degree of neuro fuzzy membership with genetic algorithms. The optimization process with genetic algorithms is as follows:

a. Initial Population Formation (Initialization)

The initial population formation is done according to the popsize parameter is 3 , the crossover probability $(\mathrm{Pc})$ is 0.5 and the probability of mutation $(\mathrm{Pm})=0.2$. The initial population generated with 3 random or random numbers or chromosomes $(\mathrm{k})$ can be seen in Table 5 . 
Table 5. Initial Population

\begin{tabular}{cccccccccc}
\hline \multicolumn{8}{c}{ Chromosoms } \\
\hline k1 & 0.74 & 0.25 & 0.063 & 0.52 & 0.22 & 0.19 & 0.81 & $\ldots$ & 0.803 \\
k2 & 0.88 & 0.48 & 0.092 & 0.5 & 0.07 & 0.85 & 0.4 & $\ldots$ & 0.013 \\
k3 & 0.85 & 0.25 & 0.885 & 0.99 & 0.89 & 0.87 & 0.15 & $\ldots$ & 0.162 \\
\hline
\end{tabular}

b. Calculation of Fitness Value Evaluation

Fitness evaluation value is

fitness $[\mathrm{i}]=$ Gen Gen value [i] can be seen in Table 6 .

Table 6. Evaluation of Fitness Value

\begin{tabular}{cccccccccccccc}
\hline No & \multicolumn{10}{c}{ Chromosoms } & \multicolumn{1}{c}{ Result } \\
\hline k1 & 0.74 & 0.25 & 0.063 & 0.52 & 0.22 & 0.19 & 0.81 & 0.047 & 0.0017 & $\ldots$ & 0.803 & 13.60187 \\
k2 & 0.88 & 0.48 & 0.092 & 0.5 & 0.07 & 0.85 & 0.4 & 0.92 & 0.2594 & $\ldots$ & 0.013 & 14.7202 \\
k3 & 0.85 & 0.25 & 0.885 & 0.99 & 0.89 & 0.87 & 0.15 & 0.165 & 0.6619 & $\ldots$ & 0.162 & 15.46656 \\
\hline
\end{tabular}

c. Chromosome Selection

Used the Roulette Wheel method with the following stages:

1) Inverse with $Q$ [i] = 1 / fitness [i]

2) The relative probability / fitness of each individual with the equation $\mathrm{P}[\mathrm{i}]=\mathrm{Q}[\mathrm{i}] / \Sigma \mathrm{Q}[\mathrm{i}]$

d. Crossover

Opportunity for crossover $(\mathrm{Pc})=0.5$, it is expected that the total chromosome will experience a crossover by means of $3 * 0.5$ the result is 2 offspring. Generate random numbers [0 1] as many as 3 pieces.

Select the number to be crossovered by selecting a random value that is less than the $\mathrm{pc}$ value, for the pc value $=0.5$. The crossover process with the two cut point crossover crossing method where selecting 2 points and the crossover is between the cut points. So the results of the crossover can be seen in Table 7 .

Table 7. New Population of Crossover Results

\begin{tabular}{cccccccccccc}
\hline \multicolumn{11}{c}{ New population } \\
\hline $\mathrm{k} 1$ & 0.85 & 0.25 & 0.89 & 0.99 & 0.895 & 0.8746 & 0.15 & 0.165 & 0.66 & $\ldots$ & 0.162 \\
$\mathrm{k} 2$ & 0.74 & 0.25 & 0.06 & 0.52 & 0.221 & 0.1887 & 0.81 & 0.047 & 0 & $\ldots$ & 0.803 \\
$\mathrm{k} 3$ & 0.88 & 0.48 & 0.09 & 0.5 & 0.068 & 0.8511 & 0.4 & 0.92 & 0.26 & $\ldots$ & 0.013 \\
\hline
\end{tabular}

e. Mutasi

Calculate the length of genes in the population by feeling anjangLength Gen $=$ popsize * enGen [i] by calculating Gen Gen 
Length $=3 * 11=33$. Choosing the position of the mutated gene by generating random numbers of 33 genes

With $\mathrm{pm}=0.2$, the number of genes to be mutated is pm $* \Sigma$ Gen [i]

$=$ bit result value. Group random numbers that have been raised based on chromosomes. Next select the gene value of each chromosome that is less than the value of $\mathrm{pm}=0.2$.

The process of mutation by exchanging selected chromosome genes is mutated by randomizing the values of these genes to form new genes. The results of the mutation process can be seen in Table 8 .

Table 8. New population results of mutations

\begin{tabular}{cccccccccc}
\hline \multicolumn{10}{c}{ New population Mutasi } \\
\hline $\mathrm{k} 1$ & 0.8549 & 0.25 & 0.561 & 0.77 & 0.76 & 0.87 & 0.15 & $\ldots$ & 0.162 \\
$\mathrm{k} 2$ & 0.7389 & 0.25 & 0.063 & 0.01 & 0.22 & 0.19 & 0.81 & $\ldots$ & 0.803 \\
$\mathrm{k} 3$ & 0.584 & 0.48 & 0.092 & 0.37 & 0.07 & 0.85 & 0.73 & $\ldots$ & 0.225 \\
\hline
\end{tabular}

f. Solution Evaluation

The process in generation 1 generated is calculated as the fitness value formed. Select the highest fitness value with maximum generation. Then a more optimal new degree of membership will be formed. Before getting a fitness value approaching 1 or a maximum of generation, the process will return to the crossover and so on.

3) Layer 2

In the second layer, which is counting the values of $\mathrm{W} 1, \mathrm{~W} 2, \mathrm{~W} 3$ on each membership function value obtained from table 8 . The following equations are used in the calculation:

$\mathrm{W}_{1}=\mu_{\mathrm{R}}\left(\mathrm{Q}_{1}\right) * \mu_{\mathrm{R}}\left(\mathrm{Q}_{2}\right) * \mu_{\mathrm{R}}\left(\mathrm{Q}_{3}\right) * \mu_{\mathrm{R}}\left(\mathrm{Q}_{4}\right) * . . * \mu_{\mathrm{R}}\left(\mathrm{Q}_{11}\right)$

$\mathrm{W}_{2}=\mu_{\mathrm{S}}\left(\mathrm{Q}_{1}\right) * \mu_{\mathrm{S}}\left(\mathrm{Q}_{2}\right) * \mu_{\mathrm{S}}\left(\mathrm{Q}_{3}\right) * \mu_{\mathrm{S}}\left(\mathrm{Q}_{4}\right) * . . * \mu_{\mathrm{S}}\left(\mathrm{Q}_{11}\right)$

$\mathrm{W}_{3}=\mu_{\mathrm{T}}\left(\mathrm{Q}_{1}\right) * \mu_{\mathrm{T}}\left(\mathrm{Q}_{2}\right) * \mu_{\mathrm{T}}\left(\mathrm{Q}_{3}\right) * \mu_{\mathrm{T}}\left(\mathrm{Q}_{4}\right) * . . * \mu_{\mathrm{T}}\left(\mathrm{Q}_{11}\right)$

Then the calculation for data -1 is obtained as shown in Table 9.

4) Table 9. Layer 2

\begin{tabular}{ccc}
\hline $\mathrm{W}_{1}$ & $\mathrm{~W}_{2}$ & $\mathrm{~W}_{3}$ \\
\hline $3.65095 \mathrm{E}-11$ & $7.81037 \mathrm{E}-06$ & $1.03012 \mathrm{E}-09$ \\
\hline
\end{tabular}

5) Layer 3

In layer 3, each neuron in this layer in the form of a neuron is still the result of calculating the ratio of firing strength $i$ (wi) to the total of firing strength in the second layer, the equation for calculating is as follows:

$$
\bar{w}_{t}=\frac{w_{i}}{w_{1}+w_{2}}, i=1,2
$$

For the calculation of the 1st data, it is as follows 


$$
\begin{aligned}
& \mathrm{W}_{1}^{-}=\frac{W_{1}}{W_{1}+W_{2}+W_{3}} \\
& \mathrm{~W}_{2}^{-}=\frac{W_{2}}{W_{1}+W_{2}+W_{3}} \\
& \mathrm{~W}_{3}^{-}=\frac{W_{3}}{W_{1}+W_{2}+W_{3}}
\end{aligned}
$$

Then the calculation results in the third layer with the first data can be seen in

Table 10. This result is known as normalized firing strength.

Table 10. Layer 3

\begin{tabular}{ccc}
\hline$\overline{\mathrm{W}}_{1}$ & $\overline{\mathrm{W}}_{2}$ & $\overline{\mathrm{W}}_{3}$ \\
\hline $4.67385 \mathrm{E}-06$ & 0.999863453 & 0.000131873 \\
\hline
\end{tabular}

6) Layer 4

In the fourth layer the Win value will be calculated to calculate the output of the fuzzyfication process with the following equation:

$\mathrm{W}_{\mathrm{i}} \mathrm{f}_{\mathrm{i}}=\mathrm{W}_{\mathrm{t}} \bar{*} \Sigma \mathrm{f}_{\mathrm{i}}$

Then the results of calculations in the fourth layer of the first data can be seen in Table 11.

Table 11. Layer 4

$\frac{\overline{\mathrm{W}}_{\mathrm{i}} \mathrm{f}_{\mathrm{i}}}{364.2584886}$

7) Layer 5

In this layer you will get results from calculations with neuro fuzzy. The results of this calculation are a diagnosis of the indication data entered. To calculate the results using equations: $\mathrm{Y}=\overline{\mathrm{W}}_{\mathrm{i}} \mathrm{f}_{\mathrm{i}} / \Sigma$ parameter $\mathrm{c}$

So that the calculation is obtained in the first data $\mathrm{Y}=364.2584886 / 155.5=2.342498319$

Neuro fuzzy calculations are carried out with training data of $60 \%$ or as many as 60 data records for the training process, while $40 \%$ data or as many as 10 data records for the data testing process. In the neuro fuzzy process after the defuzzyfication process, the accuracy value of typhoid fever is $80 \%$ with the number of data records corresponding to the actual value of 32 data from the total 40 data records.

Then genetic algorithm optimization is carried out in the process of forming the degree of neuro fuzzy membership. After optimization with genetic algorithms resulted in an increase in accuracy from $80 \%$ to $90 \%$ with the number of data records that correspond to the actual value of 36 data from the total 40 data records. The table of results of neuro fuzzy optimization using genetic algorithms for the diagnosis of typhoid fever can be seen in Table 12. 
Table 12. Results of Neuro Fuzzy Optimization using Genetic Algorithms for Diagnosis of Typhoid Fever

\begin{tabular}{|c|c|c|c|c|c|c|c|c|c|c|c|c|c|c|}
\hline \multirow[b]{2}{*}{ No } & \multicolumn{7}{|c|}{ Physical indication } & \multicolumn{5}{|c|}{ Blood test } & \multirow{2}{*}{$\begin{array}{c}\text { Actu } \\
\text { al }\end{array}$} & \multirow{2}{*}{$\begin{array}{c}\text { Algen+ } \\
\text { Neuro } \\
\text { Fuzzy }\end{array}$} \\
\hline & $\begin{array}{l}\mathrm{M} \\
/ \mathrm{F} \\
\end{array}$ & $\begin{array}{l}\mathrm{Fe} \\
\text { ver }\end{array}$ & $\begin{array}{l}\mathrm{Pa} \\
\text { in }\end{array}$ & $\begin{array}{l}\text { Head } \\
\text { ache }\end{array}$ & $\begin{array}{c}\mathrm{Na} \\
\text { use } \\
\mathrm{a} \\
\end{array}$ & $\begin{array}{l}\text { Diar } \\
\text { rhea }\end{array}$ & $\begin{array}{l}\text { Tempe } \\
\text { rature }\end{array}$ & $\begin{array}{l}\text { Hemo } \\
\text { globin }\end{array}$ & $\begin{array}{c}\text { Leuko } \\
\text { cytes }\end{array}$ & $\begin{array}{l}\text { Erythr } \\
\text { ocytes }\end{array}$ & $\begin{array}{c}\text { Hematr } \\
\text { ocytes }\end{array}$ & $\begin{array}{l}\text { Plat } \\
\text { elets }\end{array}$ & & \\
\hline $\begin{array}{c}34- \\
42- \\
42 \\
35-\end{array}$ & M & 5 & 3 & 3 & 3 & 3 & 36.5 & 13.2 & 7.6 & 4.6 & 38.1 & 317 & High & High \\
\hline $\begin{array}{l}20- \\
42 \\
01-\end{array}$ & M & 7 & 2 & 3 & 2 & 1 & 36.5 & 9.6 & 6.2 & 4.5 & 28.4 & 204 & $\begin{array}{l}\text { Mod } \\
\text { erate }\end{array}$ & $\begin{array}{l}\text { Moder } \\
\text { ate }\end{array}$ \\
\hline $\begin{array}{c}88- \\
42 \\
10-\end{array}$ & M & 8 & 2 & 2 & 3 & 2 & 36.5 & 14 & 6.5 & 5.2 & 40.6 & 145 & $\begin{array}{l}\text { Mod } \\
\text { erate }\end{array}$ & $\begin{array}{c}\text { Moder } \\
\text { ate }\end{array}$ \\
\hline $\begin{array}{l}23- \\
.42 \\
34-\end{array}$ & M & 7 & 2 & 2 & 2 & 2 & 37.5 & 15.6 & 6.9 & 5.3 & 43 & 87 & $\begin{array}{l}\text { Mod } \\
\text { erate }\end{array}$ & $\begin{array}{c}\text { Moder } \\
\text { ate }\end{array}$ \\
\hline $\begin{array}{c}48- \\
32 \\
36-\end{array}$ & $\mathrm{F}$ & 5 & 3 & 2 & 2 & 2 & 40 & 10.1 & 5 & 4.3 & 29.8 & 187 & $\begin{array}{l}\text { Mod } \\
\text { erate }\end{array}$ & $\begin{array}{c}\text { Moder } \\
\text { ate }\end{array}$ \\
\hline $\begin{array}{l}05- \\
22 \\
36-\end{array}$ & $\mathrm{F}$ & 8 & 3 & 2 & 2 & 2 & 36 & 11.8 & 10.8 & 4.2 & 33.2 & 225 & $\begin{array}{l}\text { Mod } \\
\text { erate }\end{array}$ & $\begin{array}{c}\text { Moder } \\
\text { ate }\end{array}$ \\
\hline $\begin{array}{l}37- \\
12\end{array}$ & M & 10 & 1 & 2 & 3 & 2 & 36 & 14 & 5.1 & 5.5 & 41.4 & 250 & $\begin{array}{l}\text { Mod } \\
\text { erate }\end{array}$ & $\begin{array}{c}\text { Moder } \\
\text { ate }\end{array}$ \\
\hline $\begin{array}{c}: \\
34-\end{array}$ & $:$ & : & $:$ & : & $:$ & $:$ & : & : & : & : & : & : & : & : \\
\hline $\begin{array}{c}40- \\
59 \\
\end{array}$ & $\mathrm{~F}$ & 7 & 3 & 1 & 1 & 1 & 38.7 & 11.3 & 13 & 4.3 & 32.8 & 213 & $\begin{array}{l}\text { Mod } \\
\text { erate }\end{array}$ & $\begin{array}{c}\text { Moder } \\
\text { ate }\end{array}$ \\
\hline
\end{tabular}

In this study, the results of accuracy are increased when the value of the degree of membership in the first neuro fuzzy layer process is optimized with genetic algorithms.

\section{CONCLUSION}

Neuro fuzzy optimization using Genetic Algorithm occurs in layer 1 which is a process of fuzzyfication and results in the value of the degree of membership from the variable input of typhoid fever indications. The optimization process with genetic algorithms is done to produce a more optimal value of membership by generating a randomized value of membership, then determining the fitness value. Repeat the crossover process with popsize $=3$, the $\mathrm{pc}$ is 0.5 and the mutation with $\mathrm{pm}$ is 0.2 to get the desired fitness value with max generation 25 . So that the value of the new membership degree is more optimal. Layers 2 and 3 are normalized firing strength and aggregation processes while layer 4 is defuzzyfication. In layer 5 it produces the output of the diagnosis with neuro fuzzy. If the output value between 0 and 1 results is Low risk, the value of 1 to 2 results is Medium risk and the output value is more than 2 High risk results. The results of the accuracy of typhoid fever diagnosis after being optimized using genetic algorithms with training data of 40 data records for typhoid fever indications resulted in $80 \%$ accuracy for fuzzy neuro and after being optimized with genetic algorithms the accuracy increased to $90 \%$. 


\section{REFERENCES}

[1] Alamsyah \& Muna, I H. (2016). Metode Fuzzy Inference System untuk PeValuean Kinerja Pegawai Perpustakaan and Pustakawan. Scientific Journal of Informatics, 3(1), 88-98.

[2] Castillo, O., Melin, P., Kacprzyk, J., \& Pedrycz, W. (2007). Type-2 Fuzzy Logic: Theory and Applications, in Granular Computing,. Granular Computing, 2007. GRC 2007. IEEE International Conference on, 145-145.

[3] Muzakir, M., Farmadi, A., \& Indriani, F. (2017). Implementasi Algoritma Neuro-Fuzzy Untuk Diagnosa Penyakit Skizofrenia. Jurnal Elektronik Nasional Teknologi and Ilmu Komputer (JENTIK), 219-231.

[4] Hani'ah, U., Arifudin, R., \& Sugiharti, E. (2016). Implementasi Adaptive NeuroFuzzy Inference System (Anfis) untuk Peramalan Pemakaian Air di Perusahaan Daerah Air Minum Tirta Moedal Semarang. Scientific Journal of Informatics, 3(1), 76-87.

[5] Kurniawati, D. O., Hidayat, R., \& Hantono, B. S. (2014). Diagnosis Penyakit Pasien Menggunakan Sistem Neuro Fuzzy. Seminar Nasional Teknologi Informasi and Komunikasi 2014 (SENTIKA 2014), 412-418.

[6] Indrianingsih, Y. (2010). Algoritma Genetik Untuk Menyelesaikan Masalah Optimasi Fungsi Berkendala dengan Pengkodean Bilangan Bulat. 2(1), 67-76.

[7] Cheng, C.B., Cheng, C.J., Lee E.S. (2002). Neuro-Fuzzy and Genetic Algorithm in Multiple Response Optimization. International Journal Computers and Mathematics with Applications, 1503-1514.

[8] Muttaqin, A., \& Sari, K. (2011). Gangguan Gastrointestinal:Aplikasi Asuhan Keperawatan Medical Bedah. Jakarta: Salemba Medika.

[9] Inawati. (2014). Fever Tifoid. Jurnal Universitas Wijaya Kusuma Surabaya, 1-6.

[10] Organization, W. (2003). Background document : The Diagnosis, treatment and prevention of typhoid fever. Geneva: World Health Organization.

[11] Parry, C., Hien, T., White, N., \& Farrar, J. (2002). Typhoid Fever. New England Jounal of Medicine, 1770-1782.

[12] Gaind, R., Paglietti, B., Murgia, M., Dawar, R., Uzzau, S., Cappuccinelli, P., Rubino, S. (2006). Molecular characterization of ciprofloxacin-resistant Salmonella enterica serovar Typhi and Paratyphi A causing enteric fever in India. Journal of Antimicrobial Chemotherapy, 1139-1144.

[13] Hatta, M., Bakker, M., Beers, S. v., Abdoel, T. H., \& Smiths, H. L. (2009). Risk Factors for Clinical Typhoid Fever in Rural South Sulawesi, Indonesia. International Journal of Tropical Medicine, 4, 91-99.

[14] Slamet, J. (2002). Kesehatan Lingkungan. Yogyakarta: Gadjah Mada University Press.

[15] Widoyono. (2008). Penyakit Tropis: Epidemiologi, Penularan, Pencegahan and Pemberantasannya. Semarang: Erlangga.

[16] Asogbon, M.G., Samuel, O.W., Omisore, M.O. \& Awonusi O. (2016). Enhanced Neuro-Fuzzy System Based on Genetic Algorithm for Medical Diagnosis. Journal Med Diagn Meth, 5, 1-10. 